Maurer School of Law: Indiana University

Digital Repository @ Maurer Law

1974

\title{
Employment Problems and the Law: A Concrete Proposal for Change
}

Julia C. Lamber

Indiana University Maurer School of Law, lamber@indiana.edu

Follow this and additional works at: https://www.repository.law.indiana.edu/facpub

Part of the Labor and Employment Law Commons, and the Legal Education Commons

\section{Recommended Citation}

Lamber, Julia C., "Employment Problems and the Law: A Concrete Proposal for Change" (1974). Articles by Maurer Faculty. 2150.

https://www.repository.law.indiana.edu/facpub/2150

This Article is brought to you for free and open access by the Faculty Scholarship at Digital Repository @ Maurer Law. It has been accepted for inclusion in Articles by Maurer Faculty by an authorized administrator of Digital Repository @ Maurer Law. For more information, please contact rvaughan@indiana.edu.

\section{$\Psi$}

LAW LIBRARY

INDIANA UNIVERSITY Maurer School of Law
Bloomington 


\title{
Employment Problems and the Law: A Concrete Proposal for Change
}

\author{
JULIA C. LAMBER*
}

IN RECENT years much has been written about teaching law at the undergraduate level.' Within this debate considerable energy has been expended in proposals and assessments for new courses.' Not only are business school faculty urged to reevaluate their programs but liberal arts faculty are active

- Assistant Profescor at Indiana Univernity Graduate School of Burineas.

I A sampling includes: Allen, Questing for a "Jurisprudence for the Millions"Some New Paramoters, 10 A.. Bus. L. J. 99 (1972); Barkman, Low-in-tho-Liboral Arts: An Appraisal and a Proposal for Experimentation $19 \mathrm{~J}$. Leons ED. 1 (1966); Berman, Treching Law Courses in the Liberal Arts College: A Challenge to the Law Schools, 13 J. Leonl ED. 47 (1960); Chayes, On Treching Low to Uadergreduates, 52 Boston U. L. Rev. 236 (1972); Donnell, The Businessman and the Business Law Curriculum, 6 Ax. Bus. L. J. 451 (1968); Dunfee and Decter, Nead and Proposal: Specific Integration of Business Lew into the Businoss School Curriculum, 7 Ax. Bus. L. J. 277 (1970); Kirkpatrick, Law and the Liberal Education, 3 Ax. Bus. L. J. 363 (1965); Martin, Lew for the Colloge Undergreducto-the Past, the Present and a Proposal, 6 Ax. Bus. L. J. 459 (1968); Schwart, Toward a Law Course for Undereraduates, 58 Ax. Bus. L. J. 838 (1972); Zelermyer, The Fusure of Business Law in Higher Education, 9 Ax. Bus. L. J. 179 (1972).

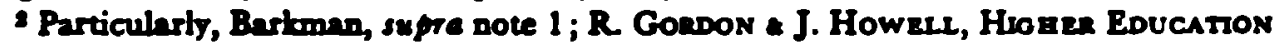
pos Bustnzes 204 (1959); Martio, supra note 1; F. Preseon, Taz Educatron or Amrucan Businessmen 212 (1959). 
as are law schools in developing new undergraduate cources. I see this inquiry as a bealthy, valuable movement as long as it inspires action. Therefore, this note provides another concrete coure propoeal, already a permanent part of a echool's curriculum, to encourage further interen in teaching methods and varied curriculum It is based on my experience with "Employment Problems and the Law" offered by the Indiana University Graduate School of Busines. After a brief discurrion of my view of the thrust of this curriculum inquiry, I will diecus come of the history pertinent to the development of the course. However, the major portion of this note is devoted to a sampling of the substantive topics presented during the course.

The dispute concerning which approach law courses should take when they are offered by busines school faculty has centered on the introductory or required course. In a simplified sense the "traditionalists" believe every business student should have a fundamental knowledge of the basic law affecting busines while the "environmentalists" believe every student should have an appreciation of the legal framework of business. It has been argued that the two sides are not really opposite or contradictory but rather focus primarily on different educational objectives and appects of learning."

Controversies over teaching methods or approaches to learning are not unique to law teaches in business schools and it is not my intention to advance a definitive solution or even to add another voice to the debate. However, the discussion about business school law courses, their approach, content, and purpose are relevant for several reasons. First, many of the articles, in arguing one side or the other, advocate various possible courses. Second, part of the controversy, perhaps unconsciously, appears to be a search for a rationaliza. tion for our existence. These points are relevant to this course note since it is another proposal and because it considers why whch a course is relevant to, indeed I believe neceseary for, busines students. Third, the existence of the debate makes it necescary for me to state my position which is decidedly middle-of-the-road. In this "advanced" course as well as in my introductory

- This course was firut offered as a permanent course in the fall, 1972, a L406, three credits It is open to all undergaduater without prerequisite and available to gradunte students through a "topics" number. For other information and background see tert accompanjing note 7 intre.

The iden for a epecific topic course at the senior level is not unique. Our department

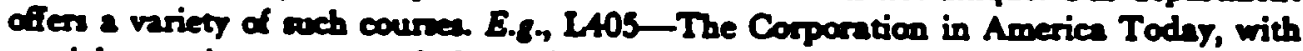
apecial artention to propocil for mating corporations more responsible to shareholders and the public; L407-Lar of Competition and Deceptive Practicen, with an emphasi on the effect of these lom upon conrumers and competitors; L408-Real Eotate Law, with an emphasis on the tools of land-ure planning; and L409-Law and the Enviranment.

1. Wolfe, Educational Objectives of Burinem Law 4-8 (unpubliched manurcript).

- See articles cited in soces 1 and 2 suprea 
course I believe the judicial process is mout exciting, memorable, and importane. On the other hand, in order to appreciate this proces, the beginning student must have some kind of context, that is, some substantive subject matter in which to see the process at work. Thus, study of rules and regulations are neceesary but not sufficient. Therefore, I consider this note to be descriptive rather than argumentative and I leave the fundamental debate to others. However, in the sense that I believe this type of course is good and neceseary for future policymakers in the business world, it is an advocation for change by inclusion."

\section{History and Background}

As a visiting faculty lecturer in the spring of 1972, I gave a seminar under a general "topics" course" entitled Race and Sex Discrimination in Employment. With ten white male students and my high expectations all of us learned a great deal. The materials were all photocopied, primarily unedited, and very difficult. The only formal evaluation was a research paper but class participation, presentation of the paper, and preliminary research work were taken into account for the final grade. During that spring our business law faculty decided to update, modify, and change our course offerings. This action provided me the opportunity to formalize my idea about a race and sex discrimination course. The curriculum proposal contemplated a much broader view than the seminar since race and sex discrimination were not the only legal problems in the employment area. Constitutional issues were relevant and an increasing number of cases raised religious and national origin discrimination as well as procedural problems. Although discrimination or civil rights issues arise in many contexts-voting, housing, domestic relations, criminal law-I chose to center the course on employment issues.

- Athough my primary intention is to offer my course as one direction curriculum change can take, it is conceivable such a course could antivfy the "law" requirement. If we assume that the specifica of a courne are not forever retained, the interaction between law and business policies becomes the core of the course. Parenthetically, contracts and contract theory are part of the course in order to deal with the courts' pre-1940 attitude of economic and labor regulations. See U.S. v. Darby, 312 U.S. 100 (1941); Weat Coast Hotel Co. v. Parrish, 300 U.S. 379 (1937); Adkins v. Children's Honpital, 261 U.S. 525 (1923); Muller v. Oregon, 208 U.S. 412 (1908); Lochner v. New York, 198 U.S. 45 (1905). However, my coune is an elective for busines school students and a strongly recommended one for some students in the School for Public and Environmental Affairs, Indiana University.

I L10-Current Busineas Problems and the Law. The deacription in the achool caralogue states:

Eramines a few selected curreat problems facing buriness or rociety and andyzes the impact of the legal orstem on these problems.

Obviouly such a course offers our faculty an ineritutionalized opportunity to experiment. 


\section{8 / American Busizess Low Jounad}

While the primary focus of the course is the federal Equal Employment Opportunity Acts, the appropriatenes of a course about employment dir crimination in a busines xchool's curriculum may not be obvious at first glance. However, employment decicions and policies are a primary concern of people in the business world. Hopefully all students either are or will be employer or employees; specific knowledge of their rights and responsibilities is enential. Secondly, firms bave recently shown an interest in people with some background in employment regulations since this is a relatively new area of governmental involvement. This interest in employment problems is not confined to people working in the personnel field but also includes policymakers and managers at all levels. Because the impetus for changing employment patterns must come from the policymakers who believe in the value of such a program, their inclusion is evential. Thirdly, the course's place in the busines achool is partially a recognition of change and of the relevance of the women's movement. Issues of social responsibility are included in business school curricula; and one of the academic goals of the women's movement is to encourage coverage and discussion of women's issues in general survey courses.

In 1972 the goal of the course was presented as follows:

The objective of the course is to expose future businesurien and other students to some of the current legal problems encountered in employment, to recognize and to discard some unwarranted asumptions which operate in this area, and to draw students from varied dixciplines who can benefit each ocher through an exchange of asmumptions and pre-judgments. Such expoeure will also encourage the future businewionan to think about some considerations which are evential to the effective operation of busineas and to see the pomible role of $\mathrm{kw}$ in providing solutions to these social problems.

While in 1974 I would say "expose future business people," I can also be more specific about the objectives and goals of the course. This course offers the student the opportunity to study in detail one specific example of government regulation of busines. From this example, the student can draw analogies to other areas, i.e., anti-trust, wage and price controls, advertising. Secondly, the courne illustrates the interrelationship of political and legal problems. By analyzing decirions and policies about employment requirements, the student gains a perspective about how society's goals are formed, protected, or compromised. For ecample, the recognition that employment is an essential measure for social acceptability must be balanced against another goal, a free

- Title VII of Civil Right Act 1964, as amonded, Equal Employment Opportunity Act of 1972, 42 U.S.C. \$2000e ot. seq.; Exec. Order No. 11246 (as amended), 3 C.P.R 402 (1970), 42 U.S.C. 82000 e (1970); Brec. Order No. 11478, 3 C.F.R. 446 (1970), 42 U.S.C. 82000 (1970) ; E.E.O.C. Guidelines, 29 C.F.R 16011604 (1973). See clso annotated course outline in appendix for other statutes discussed. 
and unfettered economy. The student also sees the effect of arbitrary, discriminatory decisions on the "work ethic" principle and the consequences of unemployment throughout society. Thirdly, the course seeks awareneses and critical thinking about the role of law in this area. Specifically, in looking at certain cases the student is asked what the law as an institution can do and, conversely, what people can do with law as a weapon. Finally, the course seeks what every course does, transferability. Afterwards, the student should be able to apply the clasuroom techniques of comparative thinking, evaluating arguments, and interpreting opinions and positions to other instances of decision-making.

\section{Present Course}

"Employment Problems and the Law" is offered once a year and open to all students without prerequisite. Enrolled students have come from the College of Arts and Sciences, Schools of Business, Education, and Public and Environmental Affairs. They have been from all claseses except freshmen and include graduates and undergraduates.' The materials used consist mainly of photocopied handouts and one issue of the Harvard Law Review. ${ }^{20} \mathrm{~A}$ though handout materials are effective because they represent recent court decisions or articles, the lack of a formal textbook is, I think, a serious problem. Without textbooks, most students feel disorganized and uncomfortable. Additionally, most of the handouts require substantial editing or copyright releases. I have searched for an adequate book but have found none suitable."1

- In the fall, 1972, the course included 2 women and 21 men, all white. There were 2 sophomores, 6 junion, 11 senion, and 4 graduates representing 15 Business students (2 of the graduate students); 6 College of Arts and Science students; 2 School of Education students (graduate students).

In the fall, 1973, the course included 9 women and 10 men one of whom was black. There were 2 cophomores, 2 juniors, 10 seniors, and 5 graduate students representing 11 Busines students (4 of the graduste students), 4 from the School for Public and Environmental Affairs, 3 from the College of Arts and Sciences (biology, journalim, poychology) and one graduate student from the School of Education.

The graduate student meet with the undergraduate clas and participate on a regular bacis. They are graded separately and their rexearch project must be more substantial than the undergraduates'. Mixing students like this does not seem unfair to anyone since no one has an extenive background in law, as they might in other disciplinea. In the two semesten the undergraduates have received higher grades than the graduates. The reacons for this are mixed and left to the reader's imagination.

${ }^{10}$ Comment, Developments in the Law-Employment Discrimination and Title VII of the Civil Rights Act of 1964, 84 Hav. L. Rvv. 1109 (1971). For more specific information about akignments see "Annotated Course Outline" in appendix.

11 There are some books which could be uned for a variation of the course as reference material; they are included in the bibliography in the appendix. However, many are not recent enough or do not cover the entire epectrum of the course. 


\section{0 / Amarican Business Lav Journa}

My clasroom method is a modified case approach. If the major point of a care is to illustrate a rule, the purpose of the diccusion is to determine whether it is a "good" or a "bad" rule, what the consequences of such a decision are or might be, and what the consequences of an opposite decision would be. In focusing on other readings and cases the class is given additional information and viewpoints in order to concentrate on matters of policy. What can the society accomplish through equal employment opportunity laws? What should be accomplished through such laws? How does one reconcile the divergent interests of the individual employer, applicant, and/or present employee? The breadth of coverage is apparent from the course outline in the appendix; however, four specific topics are particularly interesting and illustrative of the kinds of problems with which the course deals.

One of the most controversial topics which has not yet been definitively resolved is the use of apparently neutral job requirements. ${ }^{20}$ These requirements when applied to members of minority groups or to one sex show a a discriminatory effect; for example, requiring police officen to be 59 "tall excludes a significant portion of women and minority group members. Such a requirement will be invalid unles the employer can show it is specifically job-related. That is, is the police function done significantly better by tall people? Even more pervasive are the problems ascociated with testing. In an age where many people are seeking legitimation through objective measures, more and more employers are using the results of tests to make employment decision, either in initial hiring or in promotion decisions. If a complainant can show that members of a protected group score significantly and disproportionately lower than others, the courts have stated that the test has a disparate effect. It is then up to the employer to show that the test is valid in both a legal and poychological sense. ${ }^{18}$ In order for a test to be valid it must be able to predict with some degree of confidence whether or not the applicant will be succeaful on a particular job for which the test was used. Obviously, in order to know the chances of success on a job, one must know what the job requires, how to measure success, and for what qualities one needs to test. For intance, a loading dock employee needs to know how to read and write in order to handle shipping orders but need not have to read or write on the eame level as a high rchool or college graduate or perform high calculations of trigonometry or calculus. The same problems are now being raised in the

12 After Title VIrs effective date, July 2, 1965, there are very few cases of overt diverimination. Rather the discrimination is rublle and indirect, urually by means of - neutral etandurd which excludes significant portions of a protected group or because it perpetuntes the effect of previous over diverimination. See, C.\&., Aebeston Worters Local 53 v. Voder, 407 F.2d 1047 (5th Cir. 1969) (nepotim); Gregory v. Litton Syitem, 316 F. Supp. 401 (C.D. Cal 1970), affd, 472 F.2d 631 (9th Cir. 1972) (dirparate efiect of arret records).

24 See Grige v. Duke Power Co., 401 U.S. 424 (1971). 
context of degree requirements. Does an applicant really need an MBA to perform a particular job in a firm? Does a high school teacher really need a Masters Degree to continue teaching?"s

In presenting various situations in which these questions arise the students deal with several policy problems. How much freedom do we and should we allow the employer in defining the kind of employee desired. If an employer wants all of his or ber employees promotable, how do we then measure the testing or other pre-employment data? ${ }^{13}$ How "job-related" is the standard? Do all or substantially all people need to perform in a superior fashion to allow the trait to be a valid measure? Finally the student also considers the consequences of requiring job-related standards. On the one hand such a policy encourages employers to think of the specifics of a job, to define good job performance, and to enlarge their choices of potential employees. On the other hand such a requirement of job relatedness, particularly in testing, may have detrimental effects. Validating tests can be expensive and an employer may drop all testing and rely on interviews and other subjective data, rather than validate a potentially valuable instrument.

A second topic of concern is the effect Title VII of the 1964 Civil Rights Act has on state protective laws and maternity or pregnancy policies. Since moot protective state laws are challenged on the basis of sex discrimination, this portion of the course deals more particularly with the problems of women workers. 10 In studying the problems of these women the class confronts in judicial or legislative form several classic myths about women workers. Women are considered to be too emotional and physically weak. ${ }^{17}$ Women must be protected from physical and moral hazards, such as being a bartender ${ }^{18}$ or working in other unsuitable occupations." Finally, there is the

14 See Baker v. Columbus School Dist., 462 F.2d 1112 (5th Cir. 1972), af'g 329 F. Supp. 706 (N.D. Ga. 1971) ; Armutead v. Starkville School Dist., 461 F.2d 276 (5th Cir. 1972), off $g$ in part and reo' $g$ in part 325 F. Supp. 560 (N.D. Mis. 1971).

$2 s$ Promotability was mised in Quarles v. Phillip Morris, 279 F. Supp. 505 (E.D. Va. 1968).

10 In the past the content of the course has focused on race and rex discrimination under Title VII. However, litigation today raises mational origin and religious diecrimination complaints more than before. At least one lesson should be devoted to each of these areas, perhaps as a bridge between traditional private employment problems and constitutional inues. The religion and mational origin topica offer an excellent opportunity to raice come basic premines of the constitution. For a few of these cases see course outline in appendix, Lewsons 11 and 23.

it See Muller v. Oregon, 208 U.S. 412 (1907); Bradwell v. Illinois, 83 U.S. 130 (Wall. 1872) ; Weeks v. Bell Tel. \& Tel. Co., 408 F.2d 228 (5th Cir. 1969) (employer's position).

10 Gocanert v. Clearly, 335 U.S. 464 (1948) ; ff. Sail'er Inn, Inc. v. Kirby, 5 Cal.3d 1, 93 Cal. Rptr. 329, 485 P.2d 529 (1971) ; Patternon Tavern \& G.O.A. v. Borough of Hawthorne, 57 N.J. 180, 270 A.2d 628 (1970).

20IND. ANN. Stat. 846-2704 (Burns Repl. 1956) (prohibite women and minon from working in mines). 


\section{2 / Americen Business Law Jounal}

myth that women don't need to work-either they have a husband to support thern or their goal is to marry and quit work. These assumptions about women mate the attitudes and policies exprewed by some employers, courts, and legislatures unsurprising. In dealing with myths and the law, the students recvaluate these assumptions and find they are not valid for all women or are irrelevant"

One particular provision of Title VII of the 1964 Civil Rights Act which affects mox sex discrimination litigation is the bona fide occupational qualification (bfoq). ${ }^{21}$ While this provision allows the employer to hire and to employ employees on the basis of sex, as well as religion and national origin," where sex, religion, or national origin is "reasonably necescary" to the businea, this exception has been narrowly construed by the courts and the E.E.O.C.2 There are many specific examples of the problems raised by the bfoq exception which the class considers but I will note only a few. Discussed is the potential conflict between Title VII and state laws which affect only women, e.g., minimum wages, maximum hours, types of work, weight lifting restrictions. The class considers whether these state laws leaven the opportunities of women workers, and if so, how to "protect" workers generally without exploiting them. Also considered are the reasons and justifications for such state laws as well as the consequences of ruling them unconstitutional."s Second, we discuss the issues raised by pregnant workers-mandatory leaves,

20 Of cours, these anumptions are not valid for all women because not all women many, bear children, or acume a mother role. Additionally, wme wive and mothen do in fact "need" to wat either because they are the bead of the family or because the male's income is low. See Wonen's Bunenu, Dert. or Lasos, Bacronound Facts on Wouen Woarens in taz Untred States (1970). Moreover, financial "need" is not the normal criterion for determining "emplopability."

21 U.S.C. \$2000e-2(e)

Notwithrtanding any other provision of this title (1) it shall not be an unlawful employment practice for an employer to hire and employ employees, ... . on the basis of his religion, ex, of antional origin in those crrtain instances where religion, ere, or mational origin is a bona fide occupational qualification reasonably necessery to the normal operation of that particular busineas or enterprise... (emphacis added)

22 It should be noted that the bfoq exception cannot apply to race because this factor could never be a renonable necensity in the normal operation of a busines. This exclusion has not been tested, however.

2s Given a narrow interpretation, the exception should not include presumptions of womea's life parterms, certinin attributes typical of a ses, or the prejudices on the part of customers, the public, or ocher exployeen. The exception is meant to apply in very limited caves such as a monan for a model, washroom attendant, or wet nurse.

24 In the eight rear hirtory of the B.E.O.C., the commintion has twice changed its ponition on tate protective lam. See 29 C.F.R. \$1604.1(b)-(c) (1966); 29 C.F.R \$1604.1 (b) (1)-(2) (1970); 29 C.F. \$1604.2 (1973). 
fringe benefits, job security, and wages.2s Important to this discuscion is the relationship of myth (women and motherhood) and employers policies in addition to the implications of accepting motherhood as a national goal. Previous rules have made working and mothering incompatible, if not impor sible, while new rules seek to treat pregnancy as any ocher temporary disability is treated. The consequences of choosing either direction are many; articulating and judging the potential outcomes are important to this material. 20

Although these two areas of the foq exception have been the most litigated, yet to be answered definitely whether or not "customer preference" is legally relevant to employment decisions. One case, Diaz v. Pan American, Inc., ${ }^{27}$ held that customer preferencd was irrelevant in determining whether men were suitable for the job of flight cabin attendant. Supporting the court's decision, however, was a narrow definition of the job of a flight attendant.

$2 s$ The Comminsion's position on pregnancy is very clear:

(a) A written or unwritten employment policy or prectice which excludes from employment applicants or employees because of pregnancy is in prima facie violation of Title VII.

(b) Disabilitie caued or contributed to by pregmancy, miscarriage, abortion, childbirth, and recovery therefrom are, for all job-related purposes, temporary dieabilities and should be treated as such under any health or temporan diability innurance or sick leave plan available in connection with employmeat. Written and unwritten employment policies and practices involving matters such a the commencement and duration of leave, the availability of extensions, the accrual of veniority and other benefits and privileges, reinstatement and payment under any health or temporary disability insurance or rick leave plan, formal or informal, shall be applied to disability due to pregnancy or childbirth on the ame terms and conditions as they tre applied to other temporary disabilitien.

(c) Where the termination of an employee who is temporarily dieabled is caused by an employmeat policy under which insufficient or no leave is available, such a termination violates the act if it has a dipparate impact on employees of one sex and is not jurtified by burines neceavity. 29 C.F.R. \$1604.10.

If maternity leaves are treated like other temporary disabilities and therefore are paid-leaves, the problem will no longer be mandatory maternity leaves but rather insuring adequate time for a leave.

In 1974 the Supreme Court declared the mandatory maternity leave policien of two school systems unconstitutional. Cleveland Bd. of Educ. v. LaFleur, 42 U.S.L.W. 4187 (U.S. Jan. 21, 1974).

20 The pregmancy guidelines have not been judicially tested and the debate continues over whether or not pregnancy is voluntary, the relevance of voluntariness, if any, and the relation of legal abortion to this issue. A rather general policy problem of whether or not to encourage people to have children is aleo relevant. Additionally, the monetary costs of ruch schemea should be connidered.

27442 F.2d 385 (5th Cir. 1971), cert. denied, 404 U.S. 950 (1971). 


\section{4 / American Business Law Jownd}

There are till many undecided quetions involving advertiring tactica, maintoining atmophere and "proper" social standards" as well as the practical and social implications of dictenting this standard to employen."

A third major topic of the course is affirmative action programs. After tudying the cources of authority for such a program, the attempted programs in Philadelphia in regard to trade unions, and the other equal opportunity laws, the clas is in a better poxition to delve into the strengths and weaknewes of affirmative action programs. Once again, analyzing stereotypes or other misconception is an important part of the classroom experience. Executive Order 11246 as amended"o prohibits federal contractors (employers receiving more than $\$ 10,000$ from the federal government) from discriminating against any employee or applicant on the bacis of sex, religion, national crigin, or race. This order extends to treatment of employees throughout their employment tenure. The "afirmative action" required, although quite complex when applied to specific situations, basically mandates an employer to evaluate his/her present work force in order to determine if women and minorities are present in all positions in adequate and appropriate numbers. Appropriateness is determined by the numbers of people (women and minorities) available and seeking work from whatever is the physical area of recruiting. With the realization that affirmative action includes the standard of availability, the students know the program does not require employers to hire unqualified people. Nor is an employer expected to have a "quota" of 51\% women employees which reflects total population percentages. The class then turns from the structural aspects to an examination of such policy questions as the value of the employer himself (herself) setting the goals, the usefulness of "timetables," and the effectiveness of the legal sanctions.

After concentrating on the employment statutes, the course turns to the area of public employment. To compare and to contrast, to separate and to analogize are important proceses bere. Before the 1964 Civil Rights Act was amended in 1972 to include most government employees, the Constitution was the most important source of protecting them from arbitrary decisions and discrimination. However, since that change, the course focuses on problems peculiar to public employees. While most of the cases arise in the education field, the principles are transferable to other areas of government employ-

28 For example, if an employer can show that a black insurance salespenon does not do as good a job eelling as a white perwon in a predominantly white seighborhood, is this relevant? Of if a restaurant owner want a cophisticated atmosphere, can be hire only male waiters? In a 'Dodge Girl' still postible?

- Although aninced with early twentieth century "rubatantive due procen," the Constitution still iname freedom of contract and notions of due proces to employern. How far can legidation 80 without an inplicit "taking" of their businew?

03 C.FR 402 (1970), 42 U.S.C. (2000e (1970); Exec. Order No. 11478, 3 C.F.R 446 (1970), $\$ 2$ U.S.C. $\$ 2000$ e (1970). 
ment. Examples of the topics considered are free speech rights, termination procedures, and loyalty oaths." In order to deal with these problems the student must be familiar with some constitutional principles. Through lectures and a few cases the student develops some sense of the parameters of the fourteenth amendment's due process and equal protection clauses as well as the fifth amendment's due process and self-incrimination clauses. In examining these concepts and cases involving the government as an employer, the student is preoccupied by two general questions: First, who should be included as a government employee (or at least protected by the Constitution), and second, why are government employees accorded special status and protection? Obviously these questions encourage the student to determine the nature and function of a constitution and its place in the order of things.

I should emphasize that in studying the cases and other material throughout the course we spend a great deal of time on the assumptions, attitudes, and consequences of decisions, rules, and policies. I believe the purpose of most employment laws is to encourage rationality and logic in this particular decision-making process. Whether or not this is a true hypothesis and whether or not it is a valid policy to pursue is something each student determines.

\section{Reaction}

Athough I have only offered Employment Problems and the Law twice and to a total of approximately 45 students, the reaction has been generally favorable. The students are coming from more diverse backgrounds and seeking more individual projects and attention. Support has also come from the School for Public and Environmental Affairs. This latter support will probably increase since the provisions of Title VII now apply to government employees which makes the entire course more relevant to its specialty. There has been interest in the course expressed by persons outside the business school including alumni, other university faculty, as well as other schools of Indiana University.

The issues in the employment field are exciting and varied and offer the undergraduate law teacher an excellent opportunity for raising the interrelationship of law and public policy, business and government regulation. Teaching the course and attempting to relate different concepts to each other into some kind of cobesive unit is challenging. I offer it as an attractive alternative to you who seek to add, modify or change the undergraduate law curriculum.

11 For a more complete list of topica, ses counse outline in appendix. 


\section{APPENDIX \\ Annotated Course Outline* \\ Employment Problems and the Law}

Lesoon 1-Introduction-The Legal Process and Equal Employment Laws

Friedman, "Structure of the Federal Court System," 3 Manitoba L. Rev. 19-25 (1969).

85 Haro. * 1111-19, 1304-13.

Lesson 2-Testing

Griggs 0. Duke Power Co., 401 U.S. 424 (1971), test validation.

Barrett, "Grey Areas in Black and White Testing," 46 Harv. Bus. Rev. 92 (1968).

84 Harv. 1119-40.

Lesoon 3-Other Neutral Requirements

Concerns the problem of apparently neutral job requirements which when applied have a disparate effect on some protected group. If this disparate effect is shown, the employer must show it is job related (similar to validating tests).

Gregory v. Litton Systems, 316 F. Supp. 401 (C.D. Cal. 1970), aff'd, 472 F.2d 631 (9th Cir. 1972).

Asbestos Workers, Local 53 v. Volger, 407 F.2d 1047 (5th Cir. 1969).

84 Haro. 1145-52.

Lesson 4-Promotion and Layoff

Quarles 0. Philip Morris, 279 F. Supp. 505 (E.D. Va. 1968), seniority systems.

84 Harv. 1155-64.

Lesson 5-Promotion and Layoff (continued)

S. Sethi, Up Against the Corporate Wall 55-83 (1971).

Local 189, United Papermakers and Paperworkers v. U.S., 416 F.2d 980 (5th Cir. 1969), cert. denied, 397 U.S. 919 (1970), seniority systems.

(These two handouts also raise the administrative problems and internal inconsistency prevalent in the early years of enforcing Title VII.)

Lesson 6-New Issues-Admissions' Test, Degree Requirements

Baker v. Columbus School District, 462 F.2d 1112 (5th Cir. 1972), off'g 329 F. Supp. 706 (N.D. Ga 1971), tests.

Armstead o. Sterkeille School District, 461 F.2d 276 (5th Cir. 1972), aff'g in part and reo'g in part 325 F. Supp. 560 (N.D. Miss. 1971), tests and degrees.

84 Harv. $1141-45,1164-66$.

(Although these two cases were decided under the fourteenth amendment's 
equal protection clause, the courts' analyses of "rational basis," "compelling state interest," and job relatedness are useful in predicting results in future cases brought under Title VII as amended.)

Lesson 7-Sex Discrimination-An Overview

Sedler, "Women's Liberation-An Overview," 47 Ind. L.J. 421, 433-45 (1972).

84 Harv. 1166-72.

"Equal Pay Act-An Overview," 1 Women's Rights L. Rep. 71 (Spring 1973).

Hodgson v. Robert Hall, 473 F.2d 589 (3d Cir. 1973), no violation of the Equal Pay Act. Contra, Hodgson v. City Stores, Inc., 332 F. Supp. 942 (M.D. Ala. 1971), Hodgson v. Sears, Roebuck and Co., 4 CCH E.P.D. I7844 (W.D. Ky. 1972).

Hodgson v. Behrens Drug Co., 475 F.2d 1041 (5th Cir. 1973), violation of Equal Pay Act.

Lesson 8-Bfoq and State Protective Laws

Bowe v. Colgate Palmolive Co., 416 F.2d 711 (7th Cir. 1969), job classifications, seniority systems, and lifting limits.

Rosenfeld v. Southern Pacific Co., 293 F. Supp. 1219 (C.D. Cal. 1968), lifting and hours limitations.

Weeks v. Southern Bell Telephone, 408 F.2d 228 (5th Cir. 1969), burden of proof.

Potlatch Forests v. Hays, 318 F. Supp. 1368 (E.D. Ark. 1970), overtime and extension theory.

84 Harv. 1176-81, 1186-95.

Guidelines, 29 C.F.R. 1604.1-1604.10 (1973).

Lesson 9-Marital Status, Pregnancy, and Fringe Benefits

LaFleur v. Cleveland Board of Education, 465 F.2d 1184 (6th Cir. 1972), aff'd, 42 U.S.L.W. 4186 (U.S. January 21, 1974), mandatory maternity leave unconstitutional.

Cohen v. Chesterfield County Board of Education, 474 F.2d 395 (4th Cir. 1973), en banc, rev'd, 42 U.S.L.W. 4186 (U.S. January 21, 1974), mandatory maternity leave constitutional.

(Addition: Cleveland Board of Education v. LaFleur, 42 U.S.L.W. 4186 (U.S. January 21, 1974), mandatory maternity leaves violation of due process.

These cases are helpful in determining the validity of private industries' policies as well as the Commission's pregnancy guidelines, 29 C.F.R. 1604.10 (1973).

Rosen v. Public Service Electric and Gas Co., 328 F. Supp. 454 (D. N.J. 1971), retirement plans. 
Getman, "Emenging Constitutional Principle of Sexual Equality," Supreme Court Reo. 157, 173-80 (1972), pregnancy and maternity leaves.

TIAA-CREF, "The Participant" July 1973 (available from TIAA-CREF, 730 Third Avenue, New York City, New York, 10017), defenses of this group's retirement plans.

84 Haro. 1172-76.

Lesson 10-Bfoq and Customer Preference

Diaz 0. Pan American World Airways, Inc., 442 F.2d 385 (5th Cir. 1971), cert. denied, 404 U.S. 950 (1971), customer preference is irrelevant.

Eslinger v. Thomes, 476 F.2d 225 (4th Cir. 1973), impropriety.

84 Harv. 1181-86.

Leson 11 and 12-New Issues-Want Ads, National Origin, Military

Frontiero v. Richardson, 411 U.S. 677 (1973), rev'g 341 F. Supp. 201 (M.D. Ala. 1972), military dependency benefits, "suspect claseification." Struck v. Secretary of Defense, 469 F.2d 1372 (9th Cir. 1972), military discharge of pregnant officer.

Espinoza 0. Farah Manufacturing Co., 462 F.2d 1331 (5th Cir. 1972), cert. granted, 411 U.S. 946 (1973), discrimination on the basis of national origin.

Brush o. San Francisco Newspaper Publishing Co., 315 F. Supp. 577 (N.D. Cal. 1970), want ads.

Lesson 13-Procedures and Remedies

"Procedures Under Title VII," 1 Women's Rights L. Rep. (No. 3, 1972).

84 Haro. 1195-1222, 1228-75.

\section{Lesson 14-Mid Term}

Leson 15 and 16-Affirmative Action

Parham v. Southwestern Bell Telephone, 433 F.2d 421 (8th Cir. 1970), affirmative action requirements.

McAdory v. Scientific Research Instrument, Inc., 41 U.S.L.W. 2971 (D.C. Md. 1973), disparity between population and employee percentages.

American Telephone and Telegraph Settlement, available from Commerce Clearing House, Inc., 4020 W. Glenlake Ave., Chicago, Ill. 60646, consent decree.

Anderson and Tersine, "Our Working Women," 16 Business Horizons 55 (February 1973).

Getman, "Emerging Constitutional Principles of Sexual Equality," Supreme Court Rev. 157, 166-73 (1972), constitutionality of affirmative action programs.

84 Haro. 1275-1304, 1152-55.

Lescon 16-Unions-Role and Responsibilities

United Rubber Workers, Local 12, v. NL.R.B., 368 F.2d 12 (5th Cir. 1966), racial discrimination as an unfair labor practice. 
United Packinghouse Workers v. N.L.R.B., 416 F.2d 1126 (D.C. Cir. 1969), employer's racial discrimination an unfair labor practice.

U.S. v. Sheet Metal Workers, Local 36, 416 F.2d 123 (8th Cir. 1969), hiring hall systems.

(Note: Some background about the theory of labor regulation and the structure of the N.L.R.B. should be provided either by a handout or by the professor, putting the above material into context.)

Lesson 17-The U.S. Constitution-Introduction

I simply outline the basic amendments we will discuss (first, fifth, fourteenth), the standards of review used, and some basic constitutional principles which arise in litigation.

Leseon 18 -State Action

Burton v. Wilmington Parking Authority, 365 U.S. 715 (1961), "state action."

Moose Lodge v. Irvis, 407 U.S. 163 (1972), liquor license does not amount to state action.

Lesson 19 -Freedom of Speech

Tinker v. Des Moines School District, 393 U.S. 503 (1969), public school students and "symbolic" speech.

James v. Central District School Committee, 461 F.2d 566 (2d Cir. 1972), public school teacher and "symbolic" speech.

Pickering v. Board of Education, 391 U.S. 563 (1968), teacher criticiom of school board policies.

Lesson 20-Freedom of Speech-Due Process

Illinois State Employees Union v. Lewis, 473 F.2d 561 (7th Cir. 1972), cert. denied, 410 U.S. 908, 943 (1973), dismissal of noncivil service public employees on the basis of political party membership or support violated the employees' fourteenth amendment rights.

United States Civil Service Commission v. National Association of Letter Carriers, 413 U.S. 548 (1973), Hatch Act, 5 U.S.C. 87324 (a) (2), constitutional.

Roth v. Board of Regents, 408 U.S. 564 (1972), dismiscal of untenured professor; cf. Perry v. Sindermann, 408 U.S. 593 (1972).

Lesson 21 - Government Demands for Information and Affirmation

G. Gunther and N. Dowling, Ceses and Materials on Constitutional Law 1300-1816 (1970), rights of public employees.

Elfbrandt $v$. Russell, 384 U.S. 11 (1966), state loyalty oath.

Keyishian v. Board of Regents, 385 U.S. 589 (1967), dismissals of public employees who were "subversives."

Lesson 22-Legislative Investigations

G. Gunther and N. Dowling, supra, 1330-41. 


\section{Leson 23-Multiple Forums}

Hutchings v. US. Industries, 428 F.2d 303 (5th Cir. 1970), no election of remedies (arbitration and Title VII).

Dewey 0. Reymolds Metal Co., 429 F.2d 324 (6th Cir. 1970), aff'd by an equally divided Court, 402 U.S. 689 (1971), election of remedies.

84 Harv. 1222-28.

(Addition: Alexander v. Gerdner-Denver Co., 42 U.S.L.W. 4214 (U.S. February 19, 1947), no election of remedies.)

Leson 24-Other Applicable Legal Principles

Martin, "Enticement of Employees," 28 Bus. Lawyer 1341 (1973), tort issues in breach of employment contract situations.

White and Camey, "OSHA Comes of Age," 28 Bus. Lawer 1309 (1973), new labor statute, Occupational Safety and Health Act, 29 U.S.C. 8651 et seq.

(Note: These two topics are used only to provide the students with some notion of the vastmess of legal principles applicable to the employment area. Depending on time, they could be expanded or deleted.)

\section{Lesson 25-Final Exam}

- A more detailed course outline may be obtained by writing Ms. Julia Lamber, Indiana University Graduate School of Business, Bloomington, Indiana 47401.

- Harv. refers to "Developments in the Law," 84 Harv. L. Rev. 1109 (1971), available for $\$ 3.00$ from Harvard Law Review, Garrett House, Cambridge, Mascachusetts 02138 .

\section{Additional Bibliography}

Becker, G. S., The Economics of Discrimination (2d ed. 1973).

Blumrosen, A., Black Employment and the Law (1971).

Greenman, R. S., and F. Schmertz, Personnel Administration and the Law (1972).

Shaeffer, R. G., Non-discrimination in Employment (1973).

Sovern, M., Legal Restraints on Racial Discrimination in Employment (1966).

Cooper and Sobel, "Seniority and Testing Under Fair Employment Laws: A General Approach to Objective Criteria of Hiring and Promotion," 82 Harv. L. Rev. 1598 (1969).

"Developments in the Law-Equal Protection," 82 Haro. L. Rev. 1065 (1969).

Equal Employment Opporturity Commission Annual Reports.

Federal Civil Right Enforcement Effort, A Report of the Commission on Civil Righe (1970). 